\title{
What Mathematic Teachers Say about the Teaching Strategies in the Implementation of Tasks
}

\author{
Jakeline Amparo Villota Enríquez ${ }^{1}$, Andréia María Pereira de Oliveira $^{2}$ \& Heriberto González Valencia ${ }^{1}$ \\ ${ }^{1}$ Education Faculty, Santiago de Cali University, Cali, Valle, Colombia \\ ${ }^{2}$ Universidade Federal da Bahia, Brazil \\ Correspondence: Heriberto González Valencia, Education Faculty, Santiago de Cali University, Cali, Valle, \\ Colombia. Tel: 57-313-720-7896. E-mail: hery77@hotmail.com
}

\author{
Received: October 27, 2017 Accepted: December 3, 2017 Online Published: December 6, 2017 \\ doi: 10.5539/elt.v11n1p65 \\ URL: http://doi.org/10.5539/elt.v11n1p65
}

\begin{abstract}
In this article we will discuss, through the explanations given by teachers who teach Mathematics, the importance of using teaching strategies in the implementation of tasks. Teachers who participated in it belong to the group "Observatory Mathematics Education" (OME- Bahia). This study was framed in a qualitative approach and data were collected through observation and an interview. The interview was conducted taking into account the observation produced through videos where the implementation of mathematical tasks was recorded, serving as support different times where teachers used different teaching strategies in order to take them up again at the time of the interviews. The results showed that in the using of each teaching strategy, there is a particular importance that is assumed by the teacher; that means, their intentions are subject to different variables.
\end{abstract}

Keywords: teaching strategies, mathematical tasks, teachers-Intentions-explanations

\section{Introductión}

This article was developed in the interest of knowing the importance of using teaching strategies in the implementation of mathematical tasks, through the explanations of teachers. The construction of this proposal was taken from the questions that arose when analyzing the videos referring to the integration of mathematical tasks, where teachers use different teaching strategies; because it is observed that each teacher has a certain intention at the time of using them.

The teaching strategies used in the implementation of mathematical tasks, regain importance at the moment the teacher justifies through the different explanations of why, how, when and where to use them, thus recognizing the usefulness of the strategies of teaching through the process of reflection, argumentation, etc. in order to rethink their respective use.

In this sense, rethinking the use of teaching strategies is not an easy task, since the pedagogical experience of the teacher necessarily constitutes a pedagogical knowledge. So, "the experience of the teacher's daily work is a pedagogical knowledge, which should be valued, and more than that, used in the service of teaching strategy that provide transformative actions and actions that are not stagnant as often happens" (Stacciarini \& Esperidião, 1999).

In fact, there are different studies that address the importance of using certain teaching strategies through the explanations expressed by the teacher. For example, in the study, entitled "Alternative approaches for teaching and learning of functions: An analysis of a non-teaching intervention" different teaching strategies are used, such as: the organization of students in small groups, whose explanations given by the teachers show that this strategy seeks to have better contact with students (Geromel \& Redling, 2012). And González, Villota and Agredo (2017) state that a teaching strategy is an integral and transversal concept in the field of education.

In this way, the aim of this article is to discuss, through the explanations presented by teachers who teach mathematics, the importance of using teaching strategies in the implementation of tasks. Thus, initially we locate the moment where each teacher implements a certain teaching strategy and then presents his/her respective explanation regarding the importance of using it. Some conceptions about the terms that they infer in the understanding of this study are presented. 


\subsection{Explanations on the Utilization of Teaching Strategies}

It is important that teachers reflect on the teaching activities they implement in classrooms, in order to streamline this process; and it is at that moment that the teacher must think, rethink and reflect on the different teaching strategies used to promote student learning (Villalobos, 2003). In other words, the process of reflection by teachers regarding the use of strategies is important for the student's learning process. As González (2015) says, teachers must keep up with the trends in teaching, this will activate new motivations and help to increase the integration of the students.

For the understanding of this article, we will define the "teaching strategies" as the guidelines the teacher integrates for promoting learning; it is about the orientations that the professor gives his students with the develop in them different capacities for the interpretation of the information found in a certain task. Villota, Villota and González (2017) propose that teaching strategies are elements that the teachers use during his pedagogical practice.

In the same way, it is understood by mathematical task, a learning situation provided by the teacher; that is, it is a situation in which the teacher proposes a type of task (exercise, problem, exploration, research, etc.) to invite the students to explore it. Mathematical tasks are focused on developing contents.

The relationship of teaching strategies through the mathematical tasks and the teacher, leads us to recognize the importance of teaching strategies at the time of being used. The use of teaching strategies goes beyond a transitive action, which means to maximize the potential of students, generating reflection and explanation of why use certain teaching strategies within any task proposed for your students (Demaria \& Romero, 2013).

Reflecting on the use of teaching strategies is essential for the teacher since it is at this moment where he/she observes, visualizes, questions and evaluates different aspects that strengthen such use within the pedagogical practice. In this sense, it is proposed, "through the evaluation strategies that the teacher reflects in terms of the achievements made both by him/her and by the students; that is, it is transcendental that the teacher, beyond using the teaching strategies, evaluated the respective use" (Feo, 2010).

Indeed, the teacher through reflection and justifications given through explanations on the use of teaching strategies, recognizes that behind the process of using strategies there are different intentions. Thus, "teaching strategies should be consigned in the programming as an important part of it, because it is a new element that will incorporate and it is necessary to select previously which one will be used in each case, in such a way that its action is strategic" (Córmack, 2004).

The study entitled, "Strategies of learning and teaching in the education of children under 6 years", presents a set of teaching strategies where each of them has an intentionality; for example, the strategy called "problem situations" is a situation that occurs in learning, when the child finds a contradiction between what he knows and understands about reality and the new information he receives from other children, the teacher and his family. Thus, the intention of this strategy is for the teacher to offer the child the necessary support to restore balance. (Córmack, 2004).

The process of selecting the strategies is fundamental for the teacher to argue what were the reasons that led $\mathrm{him} / \mathrm{her}$ to select a set of strategies, since that may affect: the content that is transmitted to students, the intellectual work they do, the work habits and the values that are put into play in the class situation; In other words, the selection of teaching strategies before being implemented, helps the teacher to be clear about his/her intentions. (Anijovich \& Mora, 2009).

The authors Feo (2010), Córmack (2004), Anijovich and Mora (2009), relate to each other recognizing the great importance of the fact that the teacher reflects and explains the use of strategies, generating an evaluation on its use in order to strengthen the pedagogical practice in the students' learning process. Thus, the use of teaching strategies has a series of intentions immersed which the teacher has in mind in order to achieve the objectives set for any task proposed to students.

Thus, the reflection and explanations made by the teacher regarding the use of teaching strategies, we found that his/her methodology (Note 1) has a great influence on why they use certain strategies. In this sense, Zarate; (2009) recognizes that the teacher's methodology plays a fundamental role when selecting teaching strategies that will be used in the development of any activity.

Next, we will present a study where three teachers, who teach mathematics through explanations and reflections, address the importance of using teaching strategies in the implementation of mathematical tasks carried out in their respective classrooms. Thus, in the next section we will present the context of this study, bringing information about the training and pedagogical practice of the teachers who participated in this research. 


\subsection{Study Context}

Cecilia, Rivaldo and Giovanna, who were part of this research and authorized the use of their true names for this purpose. The interviews carried out with the teachers were made based on the observation process where the videos related to the implementation of the tasks were collected and addressed in their classrooms. In addition, it is important to highlight that the three professors are members of the collaborative group "Observatory of Mathematics Education" (OME); and it was in this study group where the interviews were developed.

The OME collaborative group is made up of undergraduate students in mathematics, researchers of mathematics education and teachers who teach mathematics in fundamental education and middle education. The objective of this group is to delineate proposals of tasks for the teaching of topics foreseen in the program of the mathematical discipline that inspire changes in the pedagogical practices.

The following table shows the respective information of the teachers: Cecilia, Giovanna and Rivaldo referring to their academic training, work experience, mathematical task implemented and objective of it.

Table 1. Information of the teachers participating in the study

\begin{tabular}{|c|c|c|c|c|}
\hline Teachers & $\begin{array}{l}\text { Academic } \\
\text { formation }\end{array}$ & Work Experience & $\begin{array}{l}\text { Mathematic } \\
\text { implemented }\end{array}$ & $\begin{array}{l}\text { Objective } \\
\text { mathematical } \\
\text { implemented }\end{array}$ \\
\hline Cecilia & $\begin{array}{l}\text { Bachelor of } \\
\text { Science and } \\
\text { Mathematics }\end{array}$ & 22 years & $\begin{array}{l}\text { Proportional } \\
\text { greatness }\end{array}$ & $\begin{array}{lcc}\text { Recognize and relate } & \text { the } \\
\text { greatness } & \text { through } & \text { flat } \\
\text { geometry. } & & \end{array}$ \\
\hline Giovanna & $\begin{array}{l}\text { Bachelor of } \\
\text { Economy with } \\
\text { complementation } \\
\text { in Mathematics }\end{array}$ & 16 years & Percentage & $\begin{array}{l}\text { Study the percentage concept } \\
\text { and its applications. }\end{array}$ \\
\hline Rivaldo & $\begin{array}{l}\text { Bachelor in } \\
\text { Mathematics }\end{array}$ & 10 years & $\begin{array}{l}\text { Location of rational } \\
\text { numbers }\end{array}$ & $\begin{array}{l}\text { Locate the rational numbers } \\
\text { on the number line. }\end{array}$ \\
\hline
\end{tabular}

Source: Villota (2016).

\section{Method of Study}

We take up some moments of the videos captured during the "observation" phase, where we locate some moments in which the teacher uses the teaching strategies in the implementation of the tasks, with the purpose of questioning, debating and observing, through their explanations, their different intentions to use certain teaching strategies.

In this way, the method used in this study is qualitative since it helped us analyze the explanations given by the teachers about the use of teaching strategies (Creswell, 2007). Being the most appropriate to promote understanding and interpretation of data.

The interviews carried out with the teachers: Cecilia, Giovanna and Rivaldo, are known as "stimulated recall interviews" and are intended to stimulate the teacher. This interview allows the teacher to relive original situations with clarity and precision when subjected to stimuli; having as purpose, in this case, to remind them of some moments recorded in the videos. The interviews were conducted through a series of questions related to teaching strategies used by teachers, generating explanations that show their importance (Reitano, 2006).

The analysis of the data of this study was carried out in stages where the data was initially coded in order to categorize them, after having made the transcriptions. The data was transcribed through the process of visualization of the videos to subsequently carry out the coding, which was a process of selection, classification and systematization of the transcribed data; filtering and crossing the data to strengthen this process (Charmaz, 2009).

\section{Presentation of the Data}

The situations presented in this section were originated from the teachers' talks: Cecilia, Rivaldo and Giovanna and in some moments the students. It should also be noted that situations are defined as the set of actions where the teacher uses teaching strategies and argues their respective use; that is to say, the situations are composed by the moment of use of the teaching strategy and the explanations presented by each teacher. 
There are eleven situations we will show, it is the number of teaching strategies used by teachers in the implementation of tasks; helping us visualize the moment of use of the strategy and its respective explanation. In addition, the situations were organized around the moments considered important and which characteristics mark the importance of using teaching strategies. Each speech is presented in separate lines through intervals to distinguish each speech from the others.

The information within the brackets indicates the actions of the teachers or explanations referring to the activities or speech made by them, within the transcript. This element helps us understand when teachers, through their speech, justify their answers regarding the importance of using teaching strategies in the implementation of the mathematical task. The “..." reluctance are symbols used to indicate a pause or suspension of the idea or teacher's speech (Brum-de-Paula \& Espinar, 2002).

The lines of the transcripts where the moment the teacher implements the specific teaching strategies were listed as of 1 and before each number we put the letter $\mathrm{O}$ to indicate the moment of the referred line. In this sense, the first line of transcription is denoted by $(\mathrm{O} 1)$, the second $(\mathrm{O} 2)$, the third (O3) and so on. In the same way, the lines of teacher interviews are listed with (E1), (E2), (E3) and so on.

Table 2. Situation 1: Organization of students in small groups

\begin{tabular}{|c|c|}
\hline Moment of implementation & Explanations \\
\hline $\begin{array}{l}\text { (O1) Cecilia: Good morning boys and girls. } \\
\text { We will work the next task in pairs and you } \\
\text { can choose who to work with. }\end{array}$ & $\begin{array}{l}\text { (E1) Cecilia: I chose the students to work in pairs because I } \\
\text { believe that the exchange of knowledge between students helps } \\
\text { in the development of the task, in terms of changing ideas: one } \\
\text { says something and the other complements. }\end{array}$ \\
\hline $\begin{array}{l}\text { (O2) Rivaldo: Please! Get together in groups } \\
\text { of five students to perform the next task. You } \\
\text { can choose who you want to work with. }\end{array}$ & $\begin{array}{l}\text { (E2) Rivaldo: The strategy of forming groups of five students } \\
\text { was to create a greater interaction among them and that the } \\
\text { dialogue could flow in a better way. }\end{array}$ \\
\hline $\begin{array}{l}\text { (O3) Giovanna: Please! Get together in } \\
\text { groups of five students, to explore the next } \\
\text { task. You can choose your partners for the } \\
\text { group. }\end{array}$ & $\begin{array}{l}\text { (E3) Giovanna: Working in small groups was intended for } \\
\text { students to interact with each other and build their own } \\
\text { reasoning through dialogue. The choice of their classmates was } \\
\text { to generate a better dialogue. }\end{array}$ \\
\hline
\end{tabular}

Source: Villota. (2016).

In fact, in (O1), (O2) and (O3) all teachers use the teaching strategy called "organization of students in small groups", where the number of students at the time of getting in groups varies. For example, teacher Cecilia formed pairs in $(\mathrm{O} 1)$; while in $(\mathrm{O} 2)$ and $(\mathrm{O} 3)$ teachers Rivaldo and Giovanna formed groups of five students. Indeed, in (E1), (E2) and (E3), teachers justify, through their explanations, the importance of implementing this teaching strategy, seeking that students interact with each other.

Table 3. Situation 2: State the purpose of the task

\begin{tabular}{ll}
\hline Moment of implementation & Explanations \\
\hline $\begin{array}{l}\text { (O1) Cecilia: We will study in this task, using the } \\
\text { contents of geometry and the relationship between } \\
\text { greatness. }\end{array}$ & $\begin{array}{l}\text { (E1) Cecilia: I think it is interesting to tell the student } \\
\text { know what they have to achieve; helping them to have } \\
\text { clarity about what the task objective is. }\end{array}$ \\
$\begin{array}{ll}\text { (O2) Rivaldo: The task we will perform involves the } \\
\text { exploration of the location of rational numbers. }\end{array}$ & $\begin{array}{l}\text { (E2) Rivaldo: It is important that the student knows } \\
\text { the objective of the task because that is where he/she } \\
\text { will perceive what the task is about. }\end{array}$ \\
$\begin{array}{ll}\text { (O3) Giovanna: The objective of the task is to study the } \\
\text { percentage concept and its applications in solving } \\
\text { problems. }\end{array}$ & $\begin{array}{l}\text { the intention of obtaining the attention and thus } \\
\text { achieve their interest to explore it. }\end{array}$
\end{tabular}

Source: Villota (2016). 
In $(\mathrm{O} 1),(\mathrm{O} 2)$ and $(\mathrm{O} 3)$ we observed that all teachers used the teaching strategy that consists of "enunciating the objective of the task", where they seek to communicate the purposes of the task to the student. Then, in (E1), (E2) and (E3) the teachers show the importance of the strategy; for example, in (E1) the teacher Cecilia seeks that the student knows what they should achieve, generating clarity regarding the objective of the task; in (E2), teacher Rivaldo asks that the student perceive what the task objective is and in (E3), the teacher Giovanna tries to get the attention of the students.

Table 4. Situation 3: Shared reading of the task

Moment of implementation
(O1) Cecilia: I will read the task, please stop what you are doing and
listen to the reading. Initially, you will build on the graph paper three
rectangles with the height of the same measurement and the bases
with different measurements. Then you will answer What the measure
of the base is? And What area does it have? In the second question in
the same graph paper you are going to construct a rectangle that must
have the measure of the base and height of your choice.

(O2) Rivaldo: Listen to the reading of the task. Today our class will be about rational numbers; that is, the task involves exploring the location of rational numbers on the number line.

Look at the number line and then answer the questions below. Are you looking at the number line?

\section{(O3)Student: Yes}

(O4) Rivaldo: Below in letter a) we must locate the following numbers on the number line above.

$$
\frac{2}{10} ;-1,5 ;-\frac{4}{2} ; 0,2 ; \frac{1}{4} ; \frac{5}{5} ; 3+\frac{1}{4} ;-\frac{8}{4} ; 2,9 ;-\frac{7}{3}
$$

Has someone already found the first number?

(O5) Students: No

(O6) Rivaldo: Then, let's try.

(O7) Giovanna: Students please stop what you are doing and listen to the reading of the task. Does anyone want to read the content of the task?

(O8) Students: [Silence]

(O9) Giovanna: Then I will read. Initially, Juan, Ana, Paulo and María inherited 4 lands of the same type and size. Each one kept a part of the land, from which they decided to plant part of the land. Juan planted 2/4 of the plot, Ana 2/5, Paulo 4/10 and María 6/20. Question 1: Who of the four uses most of the land? Explain your answer Question 2: Suppose that each one distributed the land in one hundred equal parts, a) represent in the box below [rectangle divided into 100 equal parts] the part of the land of each one, b) What would be your answer for question 1 , using the box above? How could you represent it without using the painting? And c) considering the amounts that each one uses, would one land be enough for all? Justify your answer.
Explanations

(E1) Cecilia: I implemented this strategy because I think the student could clarify more about what the task consisted of and thus clear doubts. The reading was an invitation I made to the student to start exploring the task and try to answer it in some way.

(E2) Rivaldo: Read the task initially by reading the first question of the task and let the students try to solve it, use this form for the second and third questions so that they will be anxious to go to the other questions. Also, if I had read all the task, it would be a lot of information for the student and my intention was to invite the student to develop the task.

(E3) Giovanna: The intention to perform the reading of the task was to draw the attention of the students because when the teacher reads they feel more confident in their way of interpreting, and that makes the student understand more easily the content of the task. However, initially I invited any student to do the reading but nobody wanted to do the reading of the task, then I asked them to listen.

Source: Villota (2016).

In (O1), (O2), (O3), ..., (O9) all the teachers used the strategy called "shared reading of the task"; which consisted of doing the reading of the content of the task. In this way, in (E1), (E2) and (E3), the teachers manifest the importance of using this strategy, seeking to invite the student to explore the task, by following the reading. 
Table 5. Situation 4: Use of intercalated questions

\begin{tabular}{ll}
\hline Moment of the implementation & Explanations \\
\hline (O2) Cecilia: Why are they pairs? & (E1) Cecilia: With this strategy I want to discover what \\
(O3) Student: Because it ends in zero. & $\begin{array}{l}\text { multiplication and division was worked then it is a } \\
\text { knowledge that the student already possesses. In }\end{array}$ \\
(O4) Cecilia: When is a number even? & $\begin{array}{l}\text { general, I always observe in the tasks what the student } \\
\text { already knows about the subject to propitiate the }\end{array}$ \\
(O5) Student: When it ends in 0,2, 4,6 and 8. & development of the task.
\end{tabular}

(O8) Cecilia: Could something similar happen with the division?

(O9) Student: Division! I'm going to try, our area is 8 which is even and I divide it by 2 and it is equals to 4 .

(O12) Cecilia: Very good!

(O13) Rivaldo: (O13) Rivaldo: What does 5 over 5 mean?

(O14) Student: 5 divided 5.

(O15) Rivaldo: Yes, and where is that number located on the line?

(O16) Student: I do not know!

(O17) Rivaldo: How much is 5 over 5 ?

(O18) Student: 1

(O19) Rivaldo: Where is 1 located on the line?

(O20) Student: [Points to 1 on the line]

(O21) Rivaldo: That situation is logical, it seems that it is 5 but it is not.

(O22) Giovanna: How do I transform 5 into 100 and 2 into 40 ?

(O23) Student: 5 times 20

(O24) Giovanna: why?

(O25) Student: Because 5 times 20 equals 100

(E2) Rivaldo: This type of class is exploratory, so the teacher asks more than he responds; in order to see to what extent the student can build the concept. Then, the strategy of the questions is implemented to know how the student was reasoning, understanding what was being done in the task.

(O26) Giovanna: And how did you get 40 ?

(O28) Student: Applying the same logic, multiply 2 times 20 equals 40 .

(O29) Giovanna: Very good!

Source: Villota (2016).

In fact, in $(\mathrm{O} 1), \ldots,(\mathrm{O} 29)$ the implementation of the strategy is shown where each teacher addresses the questions intercalated according to the theme contained in the different tasks implemented; that is, the teaching strategy called, "use of alternate questions".

In (E1), (E2) and (E3) we observe that teachers share their explanations regarding the usefulness of this strategy. 
Table 6. Situation 5: Promote interaction among students

\begin{tabular}{|c|c|}
\hline Moment of the implementation & Explanations \\
\hline $\begin{array}{l}\text { (O1) Student 1: In the first question I think Maria } \\
\text { used most of the land. What do you think? } \\
\text { (O2) Student 2: Why do you think it is Maria? } \\
\text { (O3) Student 1: She has six twenties of the land. } \\
\text { (O4) Student 2: It could also be Juan. But what is } \\
\text { six twenties of the land? }\end{array}$ & $\begin{array}{l}\text { (E1) Cecilia: I use this strategy because I believe that the } \\
\text { conversation between the students help. I had times, mainly } \\
\text { those of the OME, which influenced me to let the student } \\
\text { speak what he/she thinks because he/she is used to ask and } \\
\text { the teacher to answer. Now, the interesting thing is to ask } \\
\text { him/her and wrap him/her in another answer where he/she } \\
\text { can use what he/she already knows. }\end{array}$ \\
\hline $\begin{array}{l}\text { (O5) Student 3: } 6 \text { in relation to } 20 \text { is, María } \\
\text { divided } 20 \text { parts and uses } 6 \text { while Juan divided } \\
\text { into } 4 \text { parts and uses 2; that is, María used more } \\
\text { parts. } \\
\text { (O6) Student 4: And why it cannot be Ana or } \\
\text { Paulo, who will use more land? } \\
\text { (O7) Student 1: By the same logic that we are } \\
\text { using. }\end{array}$ & $\begin{array}{l}\text { (E2) Rivaldo: I implemented this strategy with the purpose } \\
\text { that the student shares his/her ideas no matter how wrong } \\
\text { they may be. The interaction is intended to feedback ideas, } \\
\text { concepts and debates. When I joined the OME, I learned } \\
\text { that as teachers we have to let the student express what } \\
\text { he/she thinks so that he/she can build his/her arguments } \\
\text { and we have to be attentive to help him/her in that } \\
\text { construction. }\end{array}$ \\
\hline $\begin{array}{l}\text { (O8) Student } 4 \text { and } 5 \text { : But it is not the only logic, } \\
\text { for example, we could convert those fractions into } \\
\text { percentages or something similar. }\end{array}$ & $\begin{array}{l}\text { (E3) Giovanna: Many times the student asks and the } \\
\text { teacher responds immediately, that was my case. After I } \\
\text { joined the OME I began to educate myself, in terms of not } \\
\text { giving the answers to the students and the fact that they } \\
\text { interact with each other helps build knowledge for } \\
\text { themselves and not to apply that traditional thing that the } \\
\text { teacher tells the student the answer without taking into } \\
\text { account that the student has a previous concepts in his/her } \\
\text { head. }\end{array}$ \\
\hline
\end{tabular}

Source: Villota (2016).

This moment of utilization of the strategy called "promoting interaction among students" presented in (O1), $(\mathrm{O} 2), \ldots,(\mathrm{O} 8)$ was selected in the implementation of the task addressed by the teacher Giovanna in a random way, meanwhile the teachers Rivaldo and Cecilia used this strategy analogously.

Next, in (E1), (E2) and (E2) the teachers recognize the great influence that the OME collaborative group has had in their pedagogical practices; strengthening the free expression of the student and thus share their thoughts.

Table 7. Situation 6: Analogies related to daily life

\begin{tabular}{|c|c|}
\hline Moment of the implementation & Explications \\
\hline $\begin{array}{l}\text { (O1) Rivaldo: The number you are looking at is } 3 \text { plus } \\
\text { another number. What number is that from here? [the } \\
\text { teacher points out the number } 1 / 4 \text { ] }\end{array}$ & \multirow{7}{*}{$\begin{array}{l}\text { (E1) Rivaldo: I think analogies help to better } \\
\text { understand mathematical concepts. Many of the } \\
\text { students know how to apply the concepts but when } \\
\text { they ask them directly, they do not know. For example, } \\
\text { when students are asked, what is } 1 / 4 \text {, they do not know } \\
\text { how to respond but if you put an action in the daily } \\
\text { routine they immediately respond because that number } \\
\text { exists in a day-to-day routine. }\end{array}$} \\
\hline (O2) Student: a quarter & \\
\hline (O3) Rivaldo: What is a quarter equivalent to? & \\
\hline (O4) Student: One divided by four. & \\
\hline (O5) Rivaldo: How much is it? & \\
\hline (O6) Student: 2 & \\
\hline $\begin{array}{l}\text { (O7) Rivaldo: If he has } \$ 1 \text { real (currency) and divides } \\
\text { into 4. How much is it? Divide on the paper. }\end{array}$ & \\
\hline (O8) Student: Ah ... teacher it is 0.25 & \\
\hline (O9) Giovanna: Jessica, how old are you? & \multirow{2}{*}{$\begin{array}{l}\text { (E2)Giovanna: The implementation of the analogies } \\
\text { strengthened in some moments of the development of }\end{array}$} \\
\hline (O10) Student (Jessica 1): 14 years old & \\
\hline
\end{tabular}


(O11) Giovanna: And the other Jessica?

(O12) Student (Jessica 2): 14 years old

(O13) Giovanna: The fact that you are the same age is wrong?

(O14) Student: No

(O15) Giovanna: The same happens in the results of our task.

Source: Villota (2016).

In $(\mathrm{O} 1), \ldots,(\mathrm{O} 15)$ we observe that each teacher uses the teaching strategy, called "analogies related to daily life" with the respective topics in the tasks; for example, teacher Rivaldo emphasizes the equivalence of fractional numbers and teacher Giovanna, in the similarity of some results.

In effect, in (E1) and (E2), the intention to use this strategy was to show the student that the mathematical concepts addressed in the tasks are used in their daily life; that is, allowing them to visualize the mathematical concepts contained in the tasks through something known.

Table 8. Situation 7: Legitimize the answers presented by the students the task that the student interpreted the information of the content of the same, my purpose was to relate those concepts of the task with those of the student's day-to-day routine.

Moment of the implementation
(O1) Student: Teacher I think $3+\overline{4}$ is a single
number and it is also a sum. I think 4 my answer is p
wrong

(O2) Rivaldo: You have to locate a single number on the line.

(O3) Student: Do I have to add 3 plus $\frac{1}{4}$ ?

(O4) Rivaldo: Yes, but remember it is a single number.

(O5) Student: The sum is 3 point 25.

(O6) Rivaldo: Very good!

(O7) Student: Now, I'm going to locate that number.

(O8) Giovanna: How did you find 130 ?

(O9) Students: Adding.

(O10) Giovanna: What amounts did you add?

(O11) Student: 40, 40, 30 and 20 which are the percentages.

(O12) Giovanna: So how many square kilometers did the heirs use?

(O13) Student: I do not believe in the sum, I am reasoning wrong.

(O14) Giovanna: Why?

(O15) Student: My answer should be in percentage and there is only $100 \%$ maximum and not $130 \%$....! I do not know!

(O16) Giovanna: Try to relate that 1 terrain represents $100 \%$.

\section{Explications}

(E1) Rivaldo: That is a way of insisting that the answer presented by the student is not correct; helping him/her to reflect and revise his/her answer again.

Source: Villota (2016).

In $(\mathrm{O} 1), \ldots,(\mathrm{O} 16)$, we try to legitimize the answers of the students, generating that they review their answers; taking into account the different topics addressed by teachers. Then, in (E1) and (E2), the student is asked to review their answers, generating security in their arguments. 
Table 9. Situation 8: Daily expressions through mathematical reiterations

\begin{tabular}{|c|c|}
\hline Moment of the implementation & Explications \\
\hline $\begin{array}{l}\text { (O1) Cecilia: What is the relationship of the height } \\
\text { with the base, when is a fixed area? You doubled the } \\
\text { height. True? }\end{array}$ & \multirow{8}{*}{$\begin{array}{l}\text { (E1) Cecilia: Particularly I like to listen on how the } \\
\text { students are thinking since they know the concept in } \\
\text { their daily life but when asked in a formally } \\
\text { mathematical way they do not respond. The purpose of } \\
\text { this strategy is to show the student that he/she knows } \\
\text { the concepts that are in the ta sk. }\end{array}$} \\
\hline (O2) Students: Yes. & \\
\hline $\begin{array}{l}\text { (O3) Cecilia: Ok! and here [presents the sheet where } \\
\text { she divided the height] }\end{array}$ & \\
\hline (O4) Student: Unfold. & \\
\hline (O5) Cecilia: What is unfolding? & \\
\hline (O6) Student: to invest. & \\
\hline (O7) Cecilia: What is to invest? & \\
\hline (O8) Student: to divide. & \\
\hline $\begin{array}{l}\text { (O9) Rivaldo: How many numbers are between } 0 \text { and } \\
1 \text { ? }\end{array}$ & \multirow{5}{*}{$\begin{array}{l}\text { (E2) Rivaldo: I try as much as possible to listen to the } \\
\text { way the students are thinking because it happens that } \\
\text { they know the concept in their daily life but when you } \\
\text { ask them formally they do not know how to respond. }\end{array}$} \\
\hline (O10) Student: Many. & \\
\hline (O11) And, how many are many? & \\
\hline (O12) Student: I know there are many. & \\
\hline (O13) Rivaldo: That is, infinities. & \\
\hline
\end{tabular}

Source: Villota (2016).

At the moment where the strategy called "everyday expressions by means of mathematical reiterations" is approached, addressed in $(\mathrm{O} 1), \ldots,(\mathrm{O} 13)$, is observed that the daily expressions presented by the student ends up leading to the formalization of the mathematical concept. In (E1) and (E2), by using this strategy, teachers seek for the student to formalize, through everyday expressions, the concepts that are immersed in the implemented tasks, generating a relationship between everyday expressions and the formal presentation of the concept.

Table 10. Situation 9: Provide "clues" through the unfolding of the task

\begin{tabular}{|c|c|}
\hline Moment of the implementation & Explications \\
\hline $\begin{array}{l}\text { (O1) Rivaldo: If you transform } 2 \text { over } 10 \text { into a } \\
\text { decimal number, what number would it be? }\end{array}$ & $\begin{array}{l}\text { (E1) Rivaldo: I provided the clues with two purposes. } \\
\text { The first was for students who stopped for not }\end{array}$ \\
\hline (O2) Student: 12 & any concept attached to the task \\
\hline $\begin{array}{l}\text { (O3) Rivaldo: Why } 12 \text { ? When is a number a decimal? } \\
\text { Read that number. }\end{array}$ & $\begin{array}{l}\text { some paths for students who did not know how to start } \\
\text { the exploration of the task. }\end{array}$ \\
\hline
\end{tabular}

(O4) Student: Two over ten

(O5) Rivaldo: Another way of saying it?

(O6) Student: Two decimals.

(O7) Rivaldo: Yes and another way to transform it? I'll give you a clue, make the division of 2 between 10 .

(O8) Student: 0 point 2.

(O9) Rivaldo: Where is that number located? Is it greater or less than 1 ?

(O10) Student: Greater.

(O11) Rivaldo: I will give you a clue, if you obtain a grade of 0 point 2 is more than obtaining 1 ?

(O12) Student: 0 point 2 is less than 1.

Cecilia: Please, pay attention for a moment! I am going to give you a clue. I am observing in the first

(E1) Cecilia: Giving the students some clues strengthened in the development of the task because 
question, that when choosing the heights and bases you are not looking at any kind of order in terms of size. If you observe that relationship it will be great. Try to place the bases in increasing order, to see if you can get to that relationship better. many of them did not know how to start and others who started did not remember some procedures to continue the exploration of it.

Source: Villota (2016).

This moment, where the strategy called "providing clues through the unfolding of the task" is implemented and addressed by the teachers Rivaldo and Cecilia, giving the student clues to the construction of the answers of the task, exploring the task as it is observed in (O1), .., (O12). Then, in (E1) and (E2), the usefulness of this strategy, seeks that the student explore the whole task by providing different alternatives for the construction of their rationales. The use of this strategy has two purposes: the first one is linked to students who advance in the development of the task but stopped because they do not remember certain concepts and the second one is related to the student who did not manage to explore the task.

Table 11. Situation 10: Socialization of the task

Moment of the implementation
(O1) Rivaldo: Who wants to explain how do I locate point a) on the
line? that is, two decimals
(O2) Student to: Me! Initially I am going to build the number line, then
as two tenths is the same as 0 comma 2 then it is going to live near 0 but
not 0 . We have to divide 1 into 10 parts and take 2 of them and so it
happens with all the rest numbers.

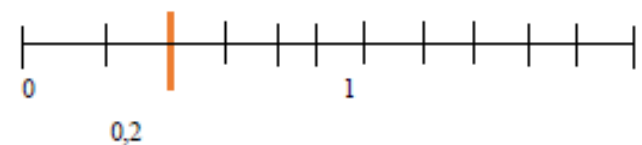

(O3) Cecilia: I will share with you a possible way to develop the task. Initially, the task will address the relationship between greatness. Then we can define greatness as what people can measure. For example, the area, that measure of a unit, such as meter, centimeters among others.

(O4) Giovanna: We will develop the task. Initially, they had to find the fraction that represents each of the quantities inherited by Juan, Paulo, Ana and María, so one way is:

$\frac{50}{100}$ can be written as 0,50 . How can I represent $\frac{40}{100} ?$

(O5) Students: 0, 40.

(O6) Giovanna: and, $\frac{30}{100} ?$

(O7) Students: 0,30.

(O8) Giovanna: Is there another way to write them?

(O9) Students: Multiplying by 100

(O10) Giovanna: How it will be?

(O11) Students: 50\%, 40\%, 40\% y 30\%

\section{Explications}

(E1) Rivaldo: The purpose of this strategy is for the student to perceive a way to develop the task and thus to understand several doubts arising in the resolution of the task.
(E2) Cecilia: This strategy helped to fit the whole process of the development of the task as the student observes, questions and takes advantage to clear their doubts that they had in the resolution of the task.

(E3) Giovanna: This strategy was intended to present the students with a way to solve the proposed task. When implementing this strategy the students shared their answers.

Source: Villota (2016). 
In effect, all teachers use this strategy as seen in $(\mathrm{O} 1),(\mathrm{O} 2),(\mathrm{O} 3), \ldots,(\mathrm{O} 11)$, where dialogue and interaction with students prevails. For example, teacher Rivaldo in $(\mathrm{O} 1)$ and $(\mathrm{O} 2)$ invites students to share their answers; in $(\mathrm{O} 3)$ the teacher Cecilia starts by defining the concept of greatness and then address the resolution of the task, and finally teacher Giovanna in (O4), ..., (O13) builds the development of the task with students' help . Indeed, in (E1), (E2) and (E3) the strategy addressed by the teachers seek to present the student with a way to solve the proposed task, generating interventions so that students clarify their doubts.

Table 12. Situation 11: Clear doubts

\begin{tabular}{|c|c|}
\hline Moment of the implementation & Explications \\
\hline $\begin{array}{l}\text { (O1) Student: teacher! What could be an example where you } \\
\text { apply the concept of inversely proportional greatness? }\end{array}$ & \multirow{2}{*}{$\begin{array}{l}\text { (E1) Cecilia: Students, by clearing doubts, are } \\
\text { experiencing the concepts of the task with their } \\
\text { daily lives. It is a very interesting process to try } \\
\text { to make that relationship. }\end{array}$} \\
\hline $\begin{array}{l}\text { (O2) Cecilia: An example, the more you run the less energy } \\
\text { you have in your body. }\end{array}$ & \\
\hline $\begin{array}{l}\text { (O3) Student: Teacher, how can the location of rational } \\
\text { numbers help me? }\end{array}$ & \multirow{2}{*}{$\begin{array}{l}\text { (E2) Rivaldo: Clear doubts is an interesting } \\
\text { process for both the student and for me because } \\
\text { it is there where I can see that the student is } \\
\text { understanding the content of the task. }\end{array}$} \\
\hline $\begin{array}{l}\text { (O4) Rivaldo: The truth for many things, one of them is to } \\
\text { locate yourself in the place where you are, when you use a } \\
\text { compass or watch. }\end{array}$ & \\
\hline $\begin{array}{l}\text { (O5) Student: Teacher that means that I can obtain by the } \\
\text { percentage the final grade of all my disciplines? }\end{array}$ & \multirow{2}{*}{$\begin{array}{l}\text { (E3) Giovanna: The fact of clearing students } \\
\text { doubts will not only help one but all as it } \\
\text { happens that several students sometimes have } \\
\text { the same question. }\end{array}$} \\
\hline (O6) Giovann & \\
\hline
\end{tabular}

Source: Villota (2016).

This strategy was used by all teachers as seen in $(\mathrm{O} 1), \ldots,(\mathrm{O} 6)$; the students clear their different doubts. Then, in (E1), (E2) and (E3), the explanations are presented showing that this strategy strengthens the implementation of the task, generating the student the opportunity to share and ask their doubts arising during the development of the task.

\section{Discussion of the Data and Conclusions}

The data presented in the previous section shows that sometimes all teachers share and employ use teaching strategies analogously, sometimes only two of them, or on the contrary none of them. Consequently, the importance of the strategies that were used by the three teachers in situations 1,2, 3, 4, 10 and 11 are presented,

In situation 1, the use of the teaching strategy called "organization of students in small groups" is addressed. According to the explanations of the teachers, students interact with each other generating a pleasant communication where they can express what they think in order to construct arguments that seek correct answers for the solution of the task.

The group's size plays a fundamental role in the development of a certain task, since the number of students influences the methodological difficulties found in the teaching of the contents. Thus, the organization of work in small groups, freely formed by the student, in which each one fulfills a role, and there are free interpersonal relationships, can be of great help to eliminate difficulties that an individualized teaching approach can entail. (Trujillo, 2010).

The organization of students in small groups means that the development of the task is done as a team. Consequently, situation 1 is related to situation 5, since one of the purposes of the small-group organization was to generate interaction among students, a strategy used by teachers to conceive a pleasant dialogue and spontaneous communication.

In situation 5, the teachers express, through their explanations, the great influence that the participation in the OME collaborative group has had on this strategy, since, often when students asked the teachers, they immediately answered without perceiving the prior knowledge; so being part of the OME help to correct this type of actions generally carried out in the pedagogical practices. 
The interaction of students through small groups has a key characteristic that distinguishes cooperative situations from other learning situations. Small groups seek to strengthen the learning process through interaction with the others members of their group, using their own language. (Webb, 1982).

In relation to situation 5, it should be noted that the intention of the OME group is linked to the teacher using strategies where the interaction among students is present, thus generating sharing of ideas and thinking among the students themselves. However, it is important to note that the teachers participating in this study are part of the OME group, it is not about any teacher who teaches mathematics; that is what makes the strengthening of their pedagogical practices since they attend the biweekly scheduled meetings, which generates, sharing their experiences.

In situation 2, teachers use the strategy called "state the purpose of the task" with the intention of communicating to the student what the task consists of; that is, to communicate the intention of the task. Thus, enunciating the objectives or educational intentions clearly describe the learning activities or purpose of certain curricular contents, as well as the expected effects that are intended to achieve in the learning of students at the end of an experience. (Díaz \& Hernández).

In situation 3, the implementation of the strategy called "shared reading of the task" used by all teachers we found that the situation is related to the previous one, given that within the heading of each task the objective was stated. Consequently, the intention to use this strategy was to invite the student to explore the task.

In this sense, some guidelines that may be useful to implement this teaching strategy are: Inform students about what reading is about, give students a purpose to listen, comment on the purpose for which students are listening and thus stimulate them. (Arderson, 1985; cited by Condemarín, 2001).

In situation 4, teachers use the strategy called "use of alternate questions", which had the intention of questioning the student by promoting the use of prior concepts. In other words, the implementation of this strategy seeks for the student to use their previous concepts through the stimulation generated by the teacher.

In this way, asking the right questions guides the students about the things they must do to solve certain problem proposed by the teacher; that is, the alternating questions have the intention of the students organizing their arguments to build the answers. (González \& Castro, 2011).

In situation 10 , we have the teaching strategy called "socialization of the task", which is closely related to situation 11 where the teaching strategy called "clearing doubts" was addressed. In these two situations, the intentions of each teacher were to share one of the solutions of the task so that the student visualizes a way to solve the proposed task; stimulating their curiosities to supply their concerns.

In this way, the socialization of any activity allows both the teacher and student to express their concerns, points of view and interpretations on a specific topic, generating motivation in students to acquire a comprehensive education that allows them to perform in the educational field. Thus, the commitment of teachers at the time of using these strategies, is to motivate students to share their different concerns, in order to clarify various doubts (Patiño, Bárcenas, \& Fernández, 2013).

On the other hand and in relation to the above mentioned, there were a set of situations where the teaching strategies used in an analogous way by two of the teachers are presented. Initially, the strategies addressed by teachers Rivaldo and Giovanna, which are: analogies related to daily life and legitimize student responses. Next, teachers Rivaldo and Cecilia implemented strategies such as: Daily expressions through mathematical reiterations and provide clues through the development of the task.

In situation 6, it can be observed the implementation of the teaching strategy called "analogies related to daily life", which had as intent to show the student that several of the concepts immersed in the tasks are used in their daily lives. However, this strategy will not necessarily represent all the mathematical concepts in the student's daily life; since there are a variety of mathematical theories that cannot be seen in everyday space; as for example, the fifth postulate of Euclid.

In fact, this strategy can be used when the information to be learned can be related with previously learned knowledge, as long as the student manages them well. Thus, some of the functions of analogies are: They increase the effectiveness of communication, provide concrete experiences to relate them to abstract and complex experiences, and improve the understanding of complex and abstract contents (Díaz \& Hernández, 2010).

In situation 7, there is the use of the teaching strategy called "legitimizing the answers presented by the students", which had the purpose of strengthening and helping to give security to the arguments presented by the students. 
In fact, legitimizing the student's response can promote advances with different depths in the content (Cutrera, Stipcich \& Chrobak 2014). In other words, the legitimization of students' responses allows them to observe, visualize and reflect on their way of reasoning, generating an in-depth analysis that will help build their arguments.

In situation 8 , the teachers used the teaching strategy called "everyday expressions by means of mathematical reiterations", the students express themselves with any non-mathematical vocabulary, and then formalize it.

In this sense, "the use of informal language is not only part of the students but also of the teachers; the use of informal language in the classroom is relevant, both by the teacher and the student, not only to facilitate the understanding of the contents through contextualization in a language that is available to the student, but is mainly, for means that informal language that students can access formal language", Llamas (2005); cited by Castro (2014).

In situation 9, the strategy called "providing clues through the unfolding of the task" is implemented, where the teachers seek that the student understands the concepts addressed in the task through similar situations. This teaching strategy highlights some important information where emphasis is made through explanations; having as a primary function helping the student in the detention of the important elements or keys elements for the development of the task. (Díaz \& Hernández, 2010).

Therefore, through the eleven situations presented in the previous section, both the mode of use of the teaching strategy and the respective explanations given by the teachers are addressed, stating their importance. So, then through the following table, the teaching strategies, some variables which influenced and the authors will be represented in a synthetic way.

Table 13. Systematization of teaching strategies

\begin{tabular}{|c|c|c|c|}
\hline Teaching Strategy & Intentionality & $\begin{array}{l}\text { Variables } \\
\text { influenced }\end{array}$ & $\begin{array}{l}\text { Authors related to the } \\
\text { intentions }\end{array}$ \\
\hline $\begin{array}{l}\text { Organization of students in } \\
\text { small groups. }\end{array}$ & $\begin{array}{l}\text { Interaction among the } \\
\text { students. }\end{array}$ & $\begin{array}{l}\text { The number of } \\
\text { students and the OME } \\
\text { group. }\end{array}$ & Trujillo, 2010. \\
\hline $\begin{array}{l}\text { Enunciation of the objective of } \\
\text { the task. }\end{array}$ & $\begin{array}{l}\text { Communicate what the } \\
\text { task consists of. }\end{array}$ & $\begin{array}{l}\text { Understanding of } \\
\text { content. }\end{array}$ & $\begin{array}{l}\text { Díaz \& Hernández, } \\
2010 .\end{array}$ \\
\hline Shared reading of the task. & $\begin{array}{l}\text { Invitation to explore the } \\
\text { task. }\end{array}$ & $\begin{array}{l}\text { Attention of the } \\
\text { students. }\end{array}$ & $\begin{array}{l}\text { Arderson, 1985, cited by } \\
\text { Condemarín, } 2001 .\end{array}$ \\
\hline Use of alternate questions. & Questioning. & Previous concepts. & $\begin{array}{l}\text { González \& Castro, } \\
\text { 2011. }\end{array}$ \\
\hline Promoting students interaction. & Interaction and dialogue. & $\begin{array}{l}\text { Participation of the } \\
\text { OME group. }\end{array}$ & Webb, 1982. \\
\hline Analogies related to daily life. & Relate. & Representations. & $\begin{array}{l}\text { Díaz \& Hernández, } \\
2010 .\end{array}$ \\
\hline $\begin{array}{l}\text { Legitimize the answers } \\
\text { presented by the students. }\end{array}$ & Security. & $\begin{array}{l}\text { Rectification } \\
\text { answers. }\end{array}$ & $\begin{array}{l}\text { Cutrera, Stipcich } \\
\text { Chrobak, } 2014 .\end{array}$ \\
\hline $\begin{array}{l}\text { Daily expressions through } \\
\text { mathematical reiterations. }\end{array}$ & Interpretation. & Verbal expressions. & $\begin{array}{l}\text { Llamas, 2005, cited by } \\
\text { Castro, 2014. }\end{array}$ \\
\hline $\begin{array}{l}\text { Provide clues through the } \\
\text { unfolding of the task. }\end{array}$ & $\begin{array}{l}\text { Help the student in the } \\
\text { development of the task. }\end{array}$ & Observe and reflect. & $\begin{array}{l}\text { Díaz \& Hernández, } \\
\text { 2010. }\end{array}$ \\
\hline Socialization of the task. & Share. & Visualize. & $\begin{array}{l}\text { Patiño, Barcenas } \\
\text { Fernandez, } 2013 .\end{array}$ \\
\hline Clear doubts. & To stimulate. & Participation. & $\begin{array}{l}\text { Patiño, Barcenas } \\
\text { Fernandez, } 2013 .\end{array}$ \\
\hline
\end{tabular}

Source: Villota (2016). 
In this table the teaching strategies used by teachers: Cecilia, Rivaldo and Giovanna had certain intentions when they were implemented, having variables that influenced at the moment of using them as; for example, the active participation of teachers within the OME group.

Finally, we can affirm that beyond using a specific teaching strategy within the process of the implementation of tasks, there is a reason why they are used; that is, intentions that can vary depending on the variables that influence the moment of using them. In this study, the teachers express the influence of the OME collaborative group in the use of some teaching strategies recovering a strong importance in their pedagogical practice.

Thus, the use of teaching strategies becomes rich as far as we, the teachers, question ourselves about why, how, when and where to use them; it is through these questions that these strategies regain importance in their implementation; they become key tools for the teaching process addressed by the teacher.

Therefore, it is crucial to remember that each teacher must be careful when using teaching strategies since all of them try to generate a better learning in the student; thus, the methodology and the way the teacher plans it, constitutes a crucial stage to determine which teaching strategies are appropriate to use. Consequently, although the teaching strategies are intended to help mediate student learning, it cannot be forgotten that behind its use there is a whole range of intentions that each teacher seeks.

\section{References}

Anijovich, R., \& Mora, S. (2009). Estrategias de enseñanza: Otra mirada al quehacer en el aula. Buenos Aires (Argentina): AIQUE.

Brum-de-Paula, M. R., Scherer, A. E., \& Paraense, S. C. L. (2002). Letras, nº 21. Santa Maria: PPGL Editores, 2002. pp. 1-13.

Charmaz, K. A. (2009). Construção da teoria fundamentada: guia prático para análise qualitativa. Tradução Joice Elias Costa. Porto Alegre: Artmed.

Creswell, J. W. (2007). Projeto de pesquisa: métodos qualitativo, quantitativo e misto.Tradução Luciana de Oliveira da Rocha. 2. ed. Porto Alegre: Artmed.

Condemarín, M. (2010). Estrategias de enseñanza para activar esquemas cognitivos de los estudiantes. Lectura y vida, 21(2), 1-17.

Cordova, B. (2012). Estrategias de enseñanza utilizadas por los docentes y su incidencia en el bajo rendimiento de los estudiantes del 7mo año de educación básica de la escuela fiscal mixta "Carlos matamoros jara" del cantón naranjito en el periodo lectivo 2011-2012. Dissertação (Maestria en Gerencia Educativa) Universidade Estadual De Milagro, Milagro, Ecuador, 152p.

Córmack, L. M. (2014). Estrategias de Aprendizaje y de Enseñanza en la Educación del menor de 6 años. Acción Pedagógica, 13(2), 154-161.

Castro, M. F. (2014). Variaciones de lenguaje (formal e informal) en el contexto educativo en la ciudad de Tefé (amazonas, br): ¿diversidad o fracaso escolar? Dissertação (Doctorado) - Universidad de Valladolid, España, $383 p$.

Cutrera, G., Stipcich, S., \& Chrobak, R. (2014). Preguntas y respuestas de un practicante durante el uso de un simulador. Un estudio de caso centrado en los intercambios discursivos. Revista Iberoamericana para la Investigación y el Desarrollo Educativo.

Demaría, J. M., \& Romero, S. (2013). La diversidad de las estrategias de enseñanza en Educación Física. Anais de $10^{\circ}$ congreso Argentino y $5^{\circ}$ Latinoamericano de Educación Física y Ciencias. Universidad Nacional de La Plata. Facultad de Humanidades y Ciencias de la Educación. Departamento de Educación Física.

Díaz, B. F., \& Hernández G. (2010). Estrategias docentes para un aprendizaje significativo, Mcgraw-Hill/Interamericana editores, s.a.de c.v., isbn: 978-607-15-0293-3, Tercera edición, México.

Feo, M. (2015) Orientaciones básicas para el diseño de estrategias didácticas. Instituto Pedagógico de Miranda. Tendencias pedagógicas, 16, 221-236.

Geromel, R. C., \& Redling, J. P. (2012). Tarefas Alternativas para o Ensino e a Aprendizagem de Funções: análise de uma intervenção no Ensino Médio. Boletim de Educação Matemática - Bolema, Rio Claro (SP), 26(42A), 193-229.

González F. M. T., \& Castro, L. C. (2011). Impacto del ABP en el Desarrollo de la Habilidad para Formular Preguntas de Aprendizaje en Estudiantes Universitarios. REDU. Revista de Docencia Universitaria, 9(1), 
57-66.

González, H. (2015). La integración de la tecnología como herramienta significativa en la enseñanza del inglés como lengua extranjera. Revista Horizontes Pedagógicos, 17(1), 53-66.

González, H., Villota, J., \& Medina, P. (2017). Strategies Used by Professors through Virtual Educational Platforms in Face-To-Face Classes: A View from the Chamilo Platform. English Language Teaching, 10(8). http://doi.org/10.5539/elt.v10n8p1

Patiño, C. H. C., Bárcenas, S., \& Fernández, M. J. (2013) Estrategias mediadas por la tecnología que contribuyen al desarrollo y socialización del conocimiento en matemáticas. Revista del Instituto de Estudios en Educación Universidad del Norte, 19, 95-106.

Reitano, P. (2006). The value of video stimulated recall in reflective teaching practices. Paper presented at the Australian Consortium for Social and Political Research Inc. (ACSPRI) Social Science Methodology Conference, New South Wales.

Stacciarini, J. M. R., \& Esperidião, E. (2015). Repensando estratégias de ensino no processo de aprendizagem. Revista latino-americana de enfermagem, Ribeirão Preto, 7(5), 59-66. https://doi.org/10.1590/S0104-11691999000500008

Trujillo, F. N. (2009). La organización de grupos-clase y de las tareas en las clases de educación física. EmásF: Revista digital de Educación Física, 1(2), 1-11.

Villalobos, J. (2015). El docente y las actividades de enseñanza/aprendizaje: algunas consideraciones teóricas y sugerencias prácticas. Educares, 7(22), 170-176.

Villota, J., Villota, M., \& González, H. (2017). Estrategias utilizadas por profesoras que enseñan en Preescolar para el desarrollo del pensamiento numérico: Una mirada desde la Educación Inicial.

Webb, N. (1992). Interacción entre estudiantes y aprendizaje en grupos pequeños. Infancia y Aprendizaje., 27(28), 159-183.

Zarate, S. (2009). Estrategias de Enseñanza para Desarrollar Habilidades del Pensamiento en la Escuela Básica estadual Caura. Dissertação (Mestrado em Ciencias de la Educación mención Procesos de Enseñanza y Aprendizaje) - Universidad Nacional Experimental de Guayana. Puerto Ordaz, Venezuela.

Note 1. According to Cordova (2012), the methodology is defined as the set of actions planned by the teacher to encourage and guide students in the learning process of students.

\section{Copyrights}

Copyright for this article is retained by the author(s), with first publication rights granted to the journal.

This is an open-access article distributed under the terms and conditions of the Creative Commons Attribution license (http://creativecommons.org/licenses/by/4.0/). 